\title{
THE INTEGRATION OF FUNDAMENTAL AND TECHNICAL ANALYSIS IN PREDICTING THE STOCK PRICE
}

\author{
Isnaini Nuzula Agustin \\ Universitas Internasional Batam \\ Email: Isnaini.nuzula@hotmail.com \\ Submitted: Feb 28, 2018; Reviewed: Mar 5, 2018; Accepted: Sept 10, 2018
}

\begin{abstract}
Fundamental Analysis and Technical Analysis have long been used by investors as an analysis instrument to predict the stock price in gaining optimal return. The purpose of this study is to test the predictive ability of Fundamental Analysis and Technical Analysis model partially, then simultaneously test the integrated model of both analysis. The scope of this study includes the listed companies in LQ 45 stock exchange during 2007- 2016 period. The Fundamental Variable used in this study are Earning per Share (EPS), Dividend Payout Ratio (DPR), and Return on Equity (ROE). The Technical Variable used is the price during the previous six months (price t-0.5), Positive extreme price increase $(D-U p)$, and Negative extreme price decline momentum (D-Down). The result of this study shows that Technical Model produces highest predictive ability compared to the other two models, while Integration model produces higher predictive ability compared to fundamental model. Using Integration model, EPS variable affects positively and significant, DPR variable affects negatively and insignificant, ROE variable, $t-0.5$, and D-Up affect positively and significant, while variable D down affects negatively and insignificant to the Stock Price. This result indicates that investors need to combine both analysis models i.e. fundamental and technical to generate optimal stock returns.
\end{abstract}

Keywords: Dividend Payout Ratio; Earning per Share; Fundamental Analysis; Stock Price; Technical Analysis

\section{INTRODUCTION}

Stock is an investment instrument that has a high level of return and risk compared to other capital market instruments. Because of its difficulty to predict, investors have to carry out stock analysis to obtain the benefit as expected. There are two basic types of stock analysis, the technical analysis and fundamental analysis. Technical analysis is an analytical technique used to predict the trend of stock prices by observing the price change in the past, especially the movement of prices, trading volume, and stock price index. In this technique the graph is the main instrument in the studying the price by the capital market practitioners. While fundamental analysis is an analytical method which is based on the economic fundamentals of a company that emphasizes on the financial ratios and events that directly or indirectly affect the company's financial performance.

The fundamental analysis and technical analysis have long been used by analysts to predict stock prices. In an effort to create the best stock performance and portfolio, investors and financial managers have to be observant and meticulous in choosing stocks and corporate decision-making. Proper technique selection to make decision greatly affects the sustainability of the company in the future, especially to improve the profitability of the company, the value per share of the company, as well as reducing the risk. Therefore, this study is conducted to compare the prediction results between technical and fundamental analysis, which of the two analysis is able to produce a higher prediction of the stock market movement in Indonesia. 
Furthermore, both the analysis will be integrated to improve the accuracy of stock prices prediction.

The three possible return that investors expect to be acquired from investing in common stock are 1) the dividends 2) Capital Gains 3) both dividend and capital gains. Therefore, dividend is one of main consoderations for investors in investment decision. On the other hand, the determination of the amount of dividend payable is an important decision that companies undertake since the objective of the firm is to optimize the shareholder's wealth as measured by the price of the company's common stock. Company has to determine what proportion of earning will be distributed for shareholders. That is why earning before tax and interest also become an important thing to be considered by investors in investment decision. Among the events which will lead to an increase in a company's earning are: successful trading on its equity, an increase in its return on equity, etc. Return on equity can help investors to distinguish between companies that are profit creator and those are profit burners. ROE helps them to measuring how much earnings that companies generate from assets, and determine whether company is lean, mean profit machine, or an inneficient clunker. Considering those illustration, we will use Earning per Share (EPS), Dividend Payout Ratio (DPR) and Return on Equity (ROE) for fundamental modeling.

As with fundamental analysis, the ability of technical analysis to explain stock price has long fascinated by practitioners and academics. While fundamental analysis try to find out the intrinsic value of companies, technical analysis argue that this method innficient. Facing market condition, investors should deal with complex variables, for example macroeconomics condition and market reactions toward good or bad reports. Technical analysis believes that previous shareprice plays big role in predicting future share price, by analyssing its movement. Another subset of technical analysis is that considering the profitability of momentum strategies, which involves the formation of portfolios based on historical performance and holding them for a predefined period.

This study covers all shares listed in LQ45 in Indonesia Stock Exchange. The index is a collection of stocks selected on the basis of certain criteria, among others the liquidity level, market capitalization and the company financial condition. Shares contained in LQ45 are liquid 94 shares that is considered to be able to represent the existing sample population. In addition to the shares in LQ45 are blue-chip stocks and the most actively traded shares and thus their performance and prospect are worthy of further studying and reviewing in the future.

\section{LITERATURE REVIEW}

Fundamental analysis is an analysis method based on the economic fundamentals of a company i.e. to calculate the stocks intrinsic value connected with company's financial data. This technique therefore focuses on company's financial ratios. Some experts consider that fundamental analysis technique is more suitable for making decision in choosing which stocks to be purchased for the long run. In addition, fundamental factors are often used by the investment analysts as they give better results and more accurate than the technical analysis (Bodie et al., 2009). Ou and Penman in Elleuch (2009) is the pioneer in the study of fundamental factors to predict the Stock Price, documenting his research on the significance of abnormal return through financial variables change prediction based on Annual Earnings per Share (EPS). Based on fundamental analysis, stock prices will reflect the company's ability in creating positive earnings in the future. Therefore, to obtain abnormal return afterwards many researchers recommend to use accounting historical data (Elleuch, 2009).

Starting from the principle that fundamental analysis aims to control and predict the key value of the company namely the revenue, Lev and Thiagarajan in Ebrahemi and Chadegani (2011) argues that fundamental analysis is also useful for predicting stock returns which is the implication of the revenue. Furthermore, Ebrahemi and Chadegani (2011) conducted the research by adding some fundamental factors that have not been studied in previous research. These factors, namely EPS and DPS. Samples taken are companies in Tehran Stock Exchange during the period of 2001-2010 on conditions that these companies have a fiscal closing period in March, and this period does not change during the study period.

Research Al-Dini et al. (2011) tested the relationship between EPS, DPS, and PER with Price stock price in Khordo Iran companies. The Research suggests that in investing in stocks, it is important to know the stock price purchased in the following years. Using Fuzzy Regression Analysis Method, the result of their research 
indicates that EPS and DPS significantly correlated to the stock price. Some research including fundamental variables also conducted years after, Sayumwe \& Amroune (2017), Warrad (2017), Thomas (2016), Gupta (2016), Zubdeh (2016), Enow \& Brijlal (2016), Issah \& Ngmenipuo (2015), Sharif, Purohit, \& Pillai (2015), Hunjra et al. (2014), Masum (2014), Vijitha \& Nimalathasan (2014), Asadi (2013), Sarwar (2013) proving that fundamental factors have significant effects to stock price and can be used to predicting future stock price.

Technical analysis is introduced for the first time by Charles H. Dow, in July 1884, Dow found the measurement of his stock market calculation. Therefore, the proposed theory is called the Dow Theory (The Theory of Dow) which is the forerunner of technical analysis that the Dow Theory is often referred to as the ancestor of technical analysis. It is mentioned that the Dow theory aims to identify the market price in the long term based on historical data of market prices in the past ( $\mathrm{Zu}$ and $\mathrm{Zhou}, 2009$ ).

In the technical analysis there are three assumptions used to conduct the assessment, namely: 1) What happens in the stock market have described some of the market conditions at that time 2) Stock prices move in trends 3) The history of stock movement patterns in the diagram can occur repeatedly. Jarret and Kyper (2011) in his technical analysis study explained that previous stock prices can be used to analyzing and predicting stock price in China. Using ARIMA modelling, ths study analyze and find a model for prediction and change, variation and interruptions in the movement of stock prices for China over time. ARIMA modelling with intervention may help analyst understand whether economic such as global financial crisis have impact on the change in chinese stock price if it exists. The model resulted with ARIMA method has a fairly high prediction i.e. $98.78 \%$.

Kumar and Singh (2011) using the comparison of several methods of prediction, namely the Simple Moving Average (SMA), Moving Average Convergencel Divergence (MACD), Stochastic Oscillator (SO), and Relative Strengh Index (RSI). The four methods consecutively are capable of generating the prediction strength power of $56.8 \%, 72.2 \%$, $64.35 \%$, and $40.32 \%$.

Some researchers namely Oberlechner (2009), Cohen (2011), and Venkatesh and Tyagi (2011) conducted a survey on stock investors of several different countries. This survey aims to see the tendency of investors in selecting stock price analysis method, namely fundamental and technical. The survey shows that investors tend to use two types of analysis simultaneously, both fundamental and technical. Technical analysis is used more by investors in Europe if the investment is applied in the short term. While fundamental analysis tend to be used for long term investment.

Through these phenomena, Bettman et al. (2009) concluded that the fundamental and technical analysis are not analysis techniques that substitute one another, but instead are complementary in nature. Investors need to perceive from various aspects in analyzing a stock, so to finally decide to buy or sell stocks. Bettman build a research model which is an integration between fundamental analysis and technical analysis. The purpose of this study is to explore the potential of the two complementary methods of analysis. The study was conducted in the United States companies in the period between the years 1983-2002, using the Book Value per Share variable (BVPS), EPS, Previous Period Stock Price, EPS Prediction (FEPS), the momentum factor of extreme positive increase (DUP) and Momentum Factor of extreme negative decline $\left(\mathrm{D}_{\text {down }}\right)$. Bettman Research shows that integration of fundamental and technical variables produce a better model compared to fundamental model or technical model partially. Integration of fundamental factors and technical factors also performed by Emir et al. (2012) in Turkish companies. A similar study by Ayodele et al. (2012), which integrates fundamental and technical factors to predict stock price, and then comparing it with technical analysis. This study resulted in the conclusion that the integration model provides better prediction capability than technical analysis.

The research model used in this study is a partial replication of Al-Dini et al. (2011) model, Kabajeh et al. (2012), Waithaka et al. (2012) for the fundamental analysis and research by Bettman (2009) for technical analysis. There are three models used in this research, namely:

1. Fundamental Analysis Research Model

Stock Price $=\beta_{0}+\beta_{1} E P S+\beta_{2} D P R+$ $\beta_{3} R O E+\varepsilon$

2. Technical Analysis Research Model

$$
\begin{aligned}
\text { Stock }_{\text {Price }} & =\beta_{0}+\beta_{1} P_{t-0.5}+\beta_{2} D_{U P} \\
& +\beta_{3} D_{D O W N}+\varepsilon
\end{aligned}
$$

3. Integration Research Model of Fundamental and Technical Factors 


$$
\begin{aligned}
\text { Stock Price }= & \beta_{0}+\beta_{1} E P S+\beta_{2} D P R \\
& +\beta_{3} R O E+\beta_{4} P_{t-0.5}+\beta_{5} D_{U P} \\
& +\beta_{6} D_{D O W N}+\varepsilon
\end{aligned}
$$

Where:

$\begin{array}{ll}\text { Stock Price } \mathrm{t} & : \text { Market price at t period } \\ \beta 0 & : \text { Intercept } \\ \beta 1 & : \text { EPS Variable } \\ \text { Regression Coefficient } & \\ \beta 2 & : \text { DPR Variable } \\ \text { Regression Coefficient } & \\ \beta 3 & : \text { ROE Variable } \\ \text { Regression Coefficient } & \\ \beta 4 & : P_{t-0.5} \text { Variable } \\ \text { Regression Coefficient } & \\ \beta 5 & : D_{U P} \text { Variable } \\ \text { Regression Coefficient } & \\ \beta 6 & : D_{D O w N} \text { Variable } \\ \text { Regression Coefficient } & \\ \text { EPS } & : \text { Income per Share } \\ \text { DPR } & : \text { Dividend Payout Ratio } \\ \text { ROE } & : \text { Return on Equity } \\ P_{t-0.5} & : \text { Stock Price in the } \\ \text { period of t- } 0.5 & : \text { Extreme price increase } \\ D_{U P} & \\ \text { Factor Momentum } & : \text { Extreme Price decline } \\ D_{D O W N} & \\ \text { Factor Momentum } & \text { Residual } \\ \varepsilon & \end{array}$

\section{RESEARCH METHOD}

Based on the formulation of the problem, this research is classified as causal comparative research, namely the type of research with the problem characteristics in the form of cause and effect relationships between two or more variables. This causal comparative research has affected variables and affecting variables (Mustafa, 2009). The object of this research is the company registered in Composite Stock Price Index (CSPI) and incorporated in LQ45 stock. The sampling selection method used was Purposive Sampling, ie each sample according to the criteria of the study, the companies that are on the LQ45 index during the year of 2007-2016. After applying those sampling technique, 56 companies were chosen during that period. Because of some outlier exists, then this data being unbalanced panel data.

This study uses two types of variables, namely the dependent variable and the independent variables. The dependent variable used in this study is the Stock Price. According Al-Dini (2011) the stock price is in the price occurring in the stock market at a given time is determined by the market participants and determined by the demand and supply of the relevant shares in the capital market. The independent variable is the type of variable that explains or affects other variables (Mustafa, 2009). Independent variables used in this study include:

1. Earning per Share (EPS)

Earning per Share (EPS) is the profit earned by the company per share. AlDhini (2011) defined for EPS equal to the equation 1.

$$
\begin{aligned}
& E P S=\frac{\text { Net Income }}{\text { Number of Stocks }} \\
& \text { (Equation 1) }
\end{aligned}
$$

2. Dividend Payout Ratio

Dividend Payout Ratio (DPR) is a dividend policy, namely the decision to determine how big the part of the net profit is after tax to be distributed to shareholders in the form of dividends or in the form of retained earnings (in the form of retained earnings) to develop the future period business. Shah (2010) mentions that the Dividend Payout Ratio (DPR) is the ratio between dividends (DPS) and EPS.

$$
\mathrm{DPR}=\frac{\text { Dividend per Stocks }}{\text { Earning per Share }}
$$

3. Return on Equity

Return on Equity (ROE) is a measurement of the efficiency achieved by the company in optimizing capital. And Mahmoud Sakr (2012) stated that ROE can be sought by comparing the net income after taxes minus preferred stock dividends to the capital.

$$
\begin{aligned}
& R O E=\frac{\text { Profit Before Income Tax }}{\text { Total Equity }} \\
& \text { (Equation 3) }
\end{aligned}
$$

4. Momentum Factor Extreme price increases (D-Up)

According to Bettman (2009), D-Up is measured using a dummy variable, having the value of 1 if the Stock Return in the previous 6 months is higher than the highest quarter of Stock Return for the previous 5 years, and having the value 0 if otherwise.

5. Extreme price Decline Factor Momentum price drop Extreme Momentum Factor (DDown) 
According to Bettman (2009), D-Down is measured using a dummy variable, having the value of 1 if the Stock Return in the previous 6 years is lower than the lowest quarter Stock Return during the previous 5 years, and having the value 0 if otherwise.

Data taken is a secondary data drawn from the company financial statements incorporated in LQ45 index, with a period of ten years of research, namely the years 2007-2016. In accordance with the purpose of research, data analysis methods that will be used are Panel RegressionAnalysis for the study intends to investigate the relationship between independent variables and the dependent variable on longitudinal data (combination of cross sectional data and time series data).

\section{RESULTS}

The resulting regression equation in fundamental analysis is:

Stock Price $_{\mathrm{t}}=3,459.34+8.87$ EPS -0.45 DPR - 756.74 ROE + e

The established regression equation explains the magnitude and impact direction of each independent variable on the dependent variable. In this model, EPS has positive impact and significant, DPR has negative and insignficant influence, while ROE has negative influence and not significant.

The resulting regression equation in the technical analysis are:

Stock Price $_{\mathrm{t}}=2,938.15+0.70$ Price $_{\mathrm{t}-0.5}+985.52$ D_Up- 481.17 D_Down + e

In the Technical Model, the stock price of the six months earlier (Price $t-0.5$ ) has a positive effect and significant, the extreme positive price increase Momentum (D-Up) has positive effect but not significant, while the momentum of the extreme negative price decline (D-Down) has a negative effect but not significant. Judging from the effect magnitude of the two dummy variables, the extreme positive price increase has a greater influence if compared to the extreme negative price decline. In this model, the momentum theory proposed by Jegadeesh and Titman is not proven.

The resulting regression equation on the fundamental analysis integration and technical analysis is:

Stock Price $=-763.29+8.10$ EPS -0.54 DPR + 1,873.26 ROE + 0.63 Price t-0.5 + 1,120.49 D-Up -297.41-Down $+\mathrm{e}$
Table 1 below presents the results of t-test generated by Panel Linear Regression models.

Table 1 The Results of t-test

\begin{tabular}{ccccccc}
\hline \multirow{2}{*}{$\begin{array}{c}\text { Variab } \\
\text { les }\end{array}$} & \multicolumn{2}{c}{ Fundamental Model } & \multicolumn{2}{c}{ Technical Models } & \multicolumn{2}{c}{ Integrated Models } \\
\cline { 2 - 7 } & $\begin{array}{c}\text { Coefficie } \\
\text { nts }\end{array}$ & $\begin{array}{c}\text { Probabi } \\
\text { lity }\end{array}$ & $\begin{array}{c}\text { Coefficie } \\
\text { nts }\end{array}$ & $\begin{array}{c}\text { Probabi } \\
\text { lity }\end{array}$ & $\begin{array}{c}\text { Coefficie } \\
\text { nts }\end{array}$ & $\begin{array}{c}\text { Probabi } \\
\text { lity }\end{array}$ \\
\hline EPS & 8,87 & 0.0000 & - & - & 8,10 & 0.0000 \\
DPR & $-0,45$ & 0.9721 & - & - & $-0,54$ & 0.9561 \\
ROE & $-756,74$ & 0.5387 & - & - & $1.873,26$ & 0.0165 \\
D-Up & - & - & 985,52 & 0.0840 & $1.120,49$ & 0.0362 \\
D- & - & - & $-481,17$ & 0.5181 & $-297,41$ & 0.6637 \\
$\begin{array}{c}\text { Down } \\
\text { Pricet- }\end{array}$ & - & - & 0,70 & 0.0000 & 0,63 & 0.0000 \\
0.5 & - & - & & & & \\
\hline
\end{tabular}

Source: Processed data

In the Integrated Model, EPS variable affects positively and significant on the stock price as the probability value loer than 0.05 . Dividend Payout Ratio affects negatively and not significant on the stock price, ROE variable affects positively and significant on the stock price, Price t-0.5 variable affects positively and significant on the stock price, variable D-Up affects positively and significant on the stock price, while the variable D-Down affects negatively and not significant on the stock price. After integrating fundamental and technical variables, ROE has the highest influence to stock price considering its regression coefficient. This result may be caused investor realized that equity is a crucial thing for companies to running its bussinesses. EPS proved to be affects positively and significant in all models, proved by all its probability values lower than 0.05 . This result indicates that the ability of companies to produces earnings is very important to investors. These results are consistent with the studies by Al Dini et al. (2011), Hatta et al. (2012), Chadegani et al. (2011), Seetharaman et al. (2011), Chang et al. (2008), Joshi (2012), Bhatt et al. (2012), Zare et al. (2011), Bettman (2009), Uddin et al. (2013), Yeob Oh et al. (2013), Khan et al. (2012), Sarwar (2013), and Emir (2012).

In accordance with the fundamental model, DPR variable affects negatively and not significant on stock price. This result is consistent Hatta (2012), but is inconsistent with Waithaka et al. research (2012). ROE is one of the tools used by investors in evaluating a stock, i.e. by measuring the level of profit generated from the shareholder's investment, in other words, a high company ROE means that the company has the opportunity to provide big income for shareholders. In accordance with the sample characteristics, the company registered in the company LQ45 is a liquid company and most frequently traded, so the capital used by the company originated from investors. In contrast to the fundamental models, by including technical 
variables in the integration model, ROE shows a positive effect and significant on the stock price. These results are consistent with Asmalidar (2011) and Khan (2012). In the integration model, Price $t_{-0.5}$ variable still shows positively and significant impact on stock price. According Jegadesh and Titman, the stock price at the middle of the year can be used to predict the stock price in the next 6 months because it reflects the company's performance in the ongoing year. These results are consistent with Bettman (2009) and Waworuntu and Suryanto (2011).

Variable D-Up which is a positive momentum stocks affect positively and significant on the stock price. Effect of ROE variable, Price $e_{t-0.5}$ and D-Up is significant so it can be generalized on the whole population. This is consistent with the stock momentum theory put forward by Bettman (2009) found that in the 3-12 month period stock return shows correlations, namely series positive inertia effect, if the six-month period stock return is investigated. Thus this proves the existence of the theory of momentum in Indonesia. Furthermore, the variable D-Down which showed poor performance of the company negatively affect the stock price. However, this effect is not significant so only apply to the sample data but can not be generalized to the whole population. This can be due to disproportionate amount of data detected as negative momentum as many as 8 , so that its effect on the dependent variable can not be detected. These results are not consistent with Bettman (2009).

Stock Price Modeling with fundamental factors, technical factors and integration factors both give different results either from regression equation model, the effect of each independent variable, or in terms of Goodness of Fit model. To determine the best model among the three models, the criteria of Goodness of Fit model is used consisting of a determination coefficient (Adjusted R-Squared), Standard Error of Regression, and Akaike Information Criteria (AIC) resulting from each regression model. Table 2 presents the value of the three criteria Goodness of Fit in each regression model.

Table 2 Goodness of Fit Model

\begin{tabular}{cccc}
\hline Goodness of Fit & Fundamental & $\begin{array}{c}\text { Model } \\
\text { Technical }\end{array}$ & Integration \\
\hline Adjusted R-Squared & $87,98 \%$ & $90,29 \%$ & $89,73 \%$ \\
Standard Error of Regression & $3.682,49$ & $3.309,07$ & $3.405,18$ \\
Akaike Information Criteria & 19,43 & 19,22 & 19,13 \\
\hline Soutrce: Processed data & &
\end{tabular}

Source: Processed data
Judging from the value of Adjusted RSquared, fundamental models give the lowest value namely equal to $87.98 \%$, followed by the integration models that is equal to $89.73 \%$. Fundamental and integration Models have a difference of Adjusted R-Squared which significant as big as $1.75 \%$. Technical model provides the highest percentage of model suitability that is equal to $90.29 \%$ which has a difference of $0.56 \%$ with Fundamental Model. This comparison is in line with other Goodness of Fit criteria, namely $\mathrm{t}$ Standard Error of Regression and Akaike Information Criteria, where the technical model gives the lowest value compared to the other two models.

In the fundamental models, the most influential variable on Stock Price is Earnings per Share. Integration Model giving better results than fundamental models, indicated by Adjusted R-Squared difference that is $1.75 \%$. This research shows that technical model is proven to be the best model compared to fundamental model and technical model, demonstrated by the high percentage of model suitability with the small rate of error. This is due to the characteristics of LQ45 index are the collection of the most liquid stocks actively traded in the stock market. According to Ayodele (2012), liquid stocks tend to follow the direction of technical cycle due to the active demand and market supply. These results prove that the Dow Theory stating that stock prices in the past can be used to predict future stock prices, simultaneously rejectingting Random Walk Hypothesis which states that the stock price in the market is formed by random and does not have a specific pattern. In the study period, LQ45 tends to rise continuously, thus forming a technical pattern that tends to better describe the prediction of future stock price. This is in line with the opinion of Venkatesh and Tyagi (2011) which states that the Technical Analysis tends to be used if the stock price shows an upward trend (bullish market), whereas fundamental analysis is used by investors when the stock price shows a decline (bearish market).

In accordance with Bettman (2009), Ayodele (2012), Emir (2012) and Waworuntu (2011) stating that the technical and fundamental analysis are complementary and is not substitutable. It means that the prediction of the stock price is more accurate by using the integration of fundamental and technical factors than just by using fundamental or technical models partially. In this model, EPS, ROE, stock 
price at $\mathrm{t}-0.5$ and $\mathrm{D}-\mathrm{Up}$ proved to significantly influence the stock price in period t. Investors can use EPS fundamental variable to determine the right time to buy or sell stocks. By integrating both factors, investors are able to make stock investment decisions to obtain maximum benefit.

\section{CONCLUDING REMARKS}

Prior studies have been conducted in order to investigate the realtionship of fundamental and technical variables in predicting stock prices. However, most of those studies only focuses on one type of analysis without reference to the other. Consequently, the literature neglects the possibility that fundamental and technical analysis could serve as complements rather than substitutes in equity valuation exercise.Folowing Betman (2009) we propose this study to compare both analysis adding by integrated model in order to bridging prior research. Testing shows that technical analysis is the best models among others. This result proving that previous stock prices can be used to predisting future prices. It is also related to the reserach object's characteristics. LQ45 known as liquid index which is most frequently traded compared to other indexes. That is why in this index technical analysis which is mostly used by trader have superior explanatory power. On the other hand, integrated model has model fit higher than fundamental model. Technical model sees considerable increases in adjusted $\mathrm{R}$ squared values and marked drops in corresponding AIC figures. Finally, the prediction from technical approach was found satisfactorily adequate as a guide for traders and investors in making investing decision.

\section{REFERENCES}

Al-Dini, S.H.M., Dehavi, D.H., \& Zarezadeh, E. (2011). Fitting the Relationship between Financial Variables and Stock Price through Fuzzy Regression Case Study: Iran Khodro Company. International Journal of Business and Social Science, 2(11), 140-146.

Ariefianto, D. (2012). Ekonometrika: Esensi dan Aplikasi dengan Menggunakan eviews. Jakarta: Erlangga.

Asadi, A. (2013). Examining the Relationship between the Dividend Policy and Stock Prices in Companies Listed on Tehran Stock Exchange. Research Journal of
Applied Sciences, Engineering and Technology, 6(22), 4186-4191.

Ashoub, M. \& Hoshmand, A. (2012). An Investigation into the Effect of Fundamental Analysis on Stocks Abnormal Return in the Companies Listed on Tehran Stock Exchange. Interdisciplinary Journal of Contemporary Research in Business, 4(2), 493-504.

Asmalidar. (2011). Analisis Faktor Fundamental terhadap Return Jangka Pendek dan Jangka Panjang Saham Initial Public Offering di Pasar Sekunder Bursa Efek Indonesia. Jurnal Ekonom, 4(4), 166-179.

Ayodele, A., Charles, A., \& Marion, A. (2012). Stock Price Prediction Using Artificial Neural Network with Hybridyzed Market Indicator. Journal of Emerging Trends of Computing and Information Sciences, 3(1), 1-9.

Bettman, J.L., Sault, S.J., \& Schultz, E.L. (2009). Fundamental and Technical Analysis: Substitutes or Complements? Journal of Accounting and Finance, 49, 21-36.

Bhatt, P. \& Sumangala, J.K. (2012). Impact of Earning per Share on Market Value of an Equity Share: An Empirical Study on Indian Stock Market. Journal of Finance, Accounting, and Management, 3(2), 1-14.

Bilal K.M. \& Gul, S. (2012). Financial Ratios and Stock Return Predictability (Evidence from Pakistan). Research Journal of Finance and Accounting, 3(10), 1-6.

Bodie, Z., Kane, A., \& Marcus, J.A. (2009). Investments $\left(8^{\text {th }}\right.$ ed.). Singapore: McGrawHill.

Chang, H.L., Su, W.C., Chen, Y.S., \& Chang, Y.W. (2008). The Relationship between Stock Price and EPS: Evidence Based on Taiwan Panel Data. Economics Bulletin, 3(30), 1-12.

Cohen, G., Kudryavtesv, A., \& Hon-Snir, S. (2011). Stock Market Analysis in Practice: Is it Technical or Fundamental? Journal of Applied Finance and Banking, 1(3), 125138.

Ebrahemi, M. \& Chadegani, A. (2011). The Relationship between Earning, Dividend, Stock Price, and Stock Return: Evidence from Irainian Companies. Proceedings of International Conference on Humanities, Society and Culture IPEDR, 20, 318-323.

Elleuch, J. (2009). Fundamental Analysis Strategy and the Prediction of Stock 
Returns. International Research Journal of Finance and Economics, 30, 95-107.

Emir, S., Dincer, H., \& Timor, M. (2012). A Stock Selection Model Based on Fundamental and Technical Analysis Variables by Using Artificial Neural Network and Support Vector Machines. Review of Economic and Finance, 106122.

Enow, S.T. \& Brijlal, P. (2016). Determinants of Share Prices: The Case of Listed Firms on Johannesburg Stock Exchange. Journal of Accounting and Management, 6(1), 85-92.

Gordon, M.T. (2009). Dividends, Earnings, and Stock Prices. Journal of the Review of Economics and Statistics, 41, 99-105.

Gupta, S. (2016). Fundamental Factors Afffecting Stock Prices of Vardham Textiles. GE-International Journal of Management Research, 4(6), 86-103.

Hatta, A.J \& Dwiyanto, B.S. (2012). The Company Fundamental Factors and Systematic Risk in Increasing Stock Price. Journal of Economics, Business, and Accountancy Ventura, 15(2), 245-256.

Hunjra, A.I., Ijaz, M.S., Chani, M.I., Hassan, S., \& Mustafa, U. (2014). Impact of Dividend Policy, Earning per Share, Return on Equity, Profit after Tax on Stock Prices. International Journal of Economics and Empirical Research, 2(3), 109-115.

Issah, O. \& Ngmenipuo, I.M. (2015). An Empirical Study of the Relationship Between Profitability Ratios and Market Share Prices of Publicly Traded Banking Financial. International Journal of Economics, Commerce and Management United, 3(12), 27-42.

Jarrett, J.E \& Kyper, E. (2011). ARIMA Modelling with Intervention to Forecast and Analyze Chinese Stock Prices. International Journal Business Management, 3(3), 53-58.

Joshi, R. (2012). Effects of Dividends on Stock Prices in Nepal. Journal of NRB Economic Review, 61-75.

Kabajeh, M.A.M., Nuaimat, S.M.A., \& Dahmash, M.N. (2012). The Relationship between the ROA, ROE, and ROI Ratios with Jordanian Insurance Public Companies Market Share Prices. International Journal of Humanities and Social Science, 2(11), 115-120.

Khan, M.B., Gul. S., Rehman, S.U., \& Razzaq, N. (2012). Financial Ratio and Stock
Return Predictability: Evidence from Pakistan. Research Journal of Finance and Accounting, 3(10), 1-5.

Kumar, A. \& Singh, R. (2011). Intelligent Stock Trading Technique Using Technical Analysis. International Journal of Management and Bussiness Studies, 1, 4749.

Masum, A. (2014). Dividend Policy and Its Impact on Stock Price - A Study on Commercial Banks Listed in Dhaka Stock Exchange. Global Disclosure of Economics and Business, 3(1), 9-20.

Mustafa, H. (2009). Metodologi Penelitian. Jakarta: Penerbit Bumi Aksara. Cetakan kesepuluh.

Oberlechner, T. (2001). Fundamental Analysis in the European Foreign Exchange Market. International Journal of Finance and Economics, 6, 81-93.

Sarwar, M.S. (2013). Effect of Dividend Policy on Share Holder's Wealth: A Study of Sugar Industry in Pakistan. Global Journal of Management and Business Research Finance, 13(7).

Sayumwe, M. \& Amroune, B. (2017). Directors Characteristics and Stock Market Performance in Canada. Journal of Economic \& Financial Studies, 5(1), 1-15. Retrieved from: https://doi.org/10.18533/jefs.v5i01.176

Seetharaman \& Raj, R.J. (2011). An Empirical Study on the Impact of Earnings per Share on Stock Prices of a Listed Bank in Malaysia. The International Journal of Applied Economics and Finance, 5(2), 114-126.

Shah, S.Z.A., Yuan, H., \& Zafar, N. (2010). Earnings Management and Dividend Policy an Empirical Comparison between Pakistani Liste Companies and Chinese Listed Companies. International Journal of Finance and Economics, 35, 51-60.

Sharif, T., Purohit, H., \& Pillai, R. (2015). Analysis of Factors Affecting Share Prices: The Case of Bahrain Stock Exchange. International Journal of Economics and Finance, 7(3), 207-216. Retrieved from: https://doi.org/10.5539/ijef.v7n3p207.

Thomas, A. (2016). The Importance of Financial Ratios in Predicting Stock Price Trends : A Case Study in Emerging Markets. Journal of Finance University Szezeein, 10(1), 1326. Retrieved from: https://doi.org/10.18276/frfu.2016.79-01. 
Truong, C. (2009). Value Investing Using Price Earnings Ratio in New Zealand. University of Auckland Business Review, 11(1).

Warrad, L.H. (2017). The Effect of Market Valuation Measures on Stock Price: An Empirical Investigation on Jordanian Banks. International Journal of Business and Social Science, 8(3), 67-74.

Uddin, R., Rahman, Z., \& Hossain, R. (2013). Determinants of Stock Prices in Financial Sector Companies in Bangladesh-A Study on Dhaka Stock Exchange (DSE). Interdisciplinary Journal of Contemporary Research in Business, 5(3), 471-480.

Venkatesh, C.K. \& Tyagi, M. (2011). Technical Analysis and its Usage in Indian Capital Market: A Survey. Bangladesh Research Publications Journal, 5(4), 282-294.

Vijitha, P. \& Nimalathasan, B. (2014). Value Relevance of Accounting Information and Share Price: A Study of Listed Manufacturing Companies in Sri Lanka. Merit Research Journal of Business and Management, 2(1), 1-6.

Waithaka, S.M., John, K.N., Jonah, K.A., Julius, K.I., \& Patrick, K. (2011). Effects of Dividend Policy on Share Price: A Case of Companies in Nairobi Securities Exchange. Prime Journal of Business Administration and Management (BAM), 2(8), 642-648.

Waworuntu, S.R \& Suryanto, H.. (2011). The Complementary Nature of Fundamental and Technical Analysis: Evidence from Indonesia. Jurnal Manajemen Bisnis, 3(2), 167-184.

Zare, I., Kandi, M.O.A., \& Beheshti, S. (2011). Role EPS to Future Earning Changes. European Journal of Economics, Finance and Administrative Sciences, Issue 43, 4449.

Zhu, Y. \& Zhou, G. (2009). Technical Analysis: An Asset Allocation Perspective on the Use of Moving Average, 92, 519-544.

Zubdeh, K.H. (2016). The Impact of Accounting Information and Macroeconomic Variables on the Stocks Market Prices of Saudi Stock Exchange. American Journal of Business and Management, 5(2), 57-66. 
Jurnal Manajemen Maranatha — Vol. 18 Nomor 2, Mei (2019) 